\title{
Młodzież zagrożona wykluczeniem w wolontariacie hospicyjnym
}

\author{
Young People Threatened by Exclusion
} in the Hospice Volunteering

\section{Opieka paliatywno-hospicyjna i jej rodzaje}

Opieka paliatywno-hospicyjna jest związana $\mathrm{z}$ ostatnim etapem życia ludzkiego i bywa proponowana $\mathrm{w}$ postaci opieki domowej lub stacjonarnej wtedy, gdy chory cierpi na zaawansowaną, nieuleczalna chorobę przewlekłą, głównie nowotworową ${ }^{1}$. Człowiek taki u kresu swojego życia najczęściej ma już za sobą liczne badania, kolejki do szpitali, chwile nadziei i czas niepomyślnych diagnoz mówiących o zakończeniu leczenia przyczynowego i skierowaniu go do instytucji lub opieki domowej. W tym ostatnim etapie ciężko chory i jego bliscy spotykają profesjonalistów z ochrony zdrowia i pomocy społecznej oraz wolontariuszy. Niesiona przez nich pomoc jest bezpłatna, finansowana przez NFZ, ale jej koszty przewyższają kwoty z kontraktu, stąd niezbędna jest pomoc wolontariuszy i społeczne wsparcie dla hospi-

$1 \quad$ P. Krakowiak, Spoteczne i edukacyjne funkcje opieki paliatywno-hospicyjnej. Badania w dziataniu 2002-2010, Gdańsk 2012. 
cjów. Obejmuje ono zwalczanie bólu, leczenie innych dolegliwości terminalnej fazy choroby, pielęgnację chorego i wsparcie dla niego i rodziny poprzez opiekę psychosocjalną i duchową. Sprawuje ją wielodyscyplinarny zespól, na który składają się lekarze, pielęgniarki, fizjoterapeuci, psychologowie, pracownicy socjalni i duchowni, a także liczna grupa wolontariuszy. Opieka ta dostępna jest najczęściej w domu chorego, poprzez domową opiekę hospicyjną, ale także w oddziałach szpitalnych, hospicjach stacjonarnych, w przychodniach oraz przez specjalistyczną opiekę nad dziećmi². Szczegółowa analiza poszczególnych form opieki nad osobami u kresu życia w ramach struktury ochrony zdrowia i pomocy społecznej wykracza poza zakres tego artykułu, ale została opisana w innym miejscu ${ }^{3}$. W niniejszym tekście zostaną przedstawione główne formy opieki paliatywno-hospicyjnej, w którą są zaangażowani wolontariusze.

Domowa opieka hospicyjna dla dorosłych. Zespół hospicjum domowego opiekuje się chorym w jego własnym domu. Zwykle udziela pomocy pacjentom w promieniu około $30 \mathrm{~km}$ od swojej siedziby. Pacjentom przysługują wizyty lekarskie, pielęgniarskie, a także interwencje psychologa, pracownika socjalnego, fizjoterapeuty, kapelana i wolontariuszy w zależności od potrzeb chorego. Zespól stara się otoczyć opieką i wspierać także najbliższych chorej osoby, zarówno za życia, jak i po śmierci pacjenta przez grupy wsparcia w żałobie. Ważną grupę w opiece domowej stanowią przeszkoleni i przygotowani wolontariusze 4 .

Hospicjum domowe dla dzieci. Wodróżnieniu od domowej opieki dla dorosłych opieką paliatywno-hospicyjną objęte są dzieci nie tylko $\mathrm{z}$ chorobą nowotworową, ale $\mathrm{z}$ każdą nieuleczalną chorobą bezpośrednio zagrażającą życiu dziecka. Pomocą hospicjum domowego może być objęte dziecko, które ma przynajmniej jednego stałego opiekuna sprawującego nad nim całodobową opiekę. Wyjazdowe zespoły hospicjum domowego udzielają pomocy w promieniu do $100 \mathrm{~km}$ od swej siedziby 5 .

2 A. Modlińska, Wolontariat medyczny, w: Podręcznik koordynatora wolontariatu bospicyjnego, red. P. Krakowiak, A. Modlińska,J. Binnebesel, Gdańsk 2008, s. 57-61.

$3 \quad$ P. Krakowiak, Wolontariat w opiece u kresu życia. Toruń 2012, s. 171-201.

4 A. Czerwiński, Gdzie po pomoc?, w: Informator dla ludzi przewlekle chorych, umierajacych i ich rodzin. „Gazeta Wyborcza” 30.10.2008, s. 20.

5 Z. Bohdan, Wolontariat hospicyjny wśród dzieci i mtodzieży-szczególne wyzwanie 
Hospicjum stacjonarne. Miejsce spełniające wszystkie wymogi oddziału medycyny paliatywnej, ale stwarzając domową i rodzinną atmosferę różnią się od nich mniejszym formalizmem i większym udziałem wolontariuszy. Najczęściej prowadzone jako Niepubliczne Zakłady Opieki Zdrowotnej przez organizacje kościelne (zakony, Caritas) albo przez stowarzyszenia i fundacje. Stacjonarna opieka hospicyjna jest bezpłatna, a duże koszty organizacji są uzupełniane przez działania charytatywne $\mathrm{z}$ udziałem wolontariuszy $\mathrm{y}^{6}$. W Polsce istnieje kilkadziesiąt tego typu ośrodków, a zaangażowanie wolontariuszy w tych placówkach jest najbardziej rozwinięte, co umożliwia zarówno ich struktura, jak i kultura wspólpracy wolontariuszy z profesjonalistami z zespołu opiekuńczego.

Hospicjum stacjonarne dla dzieci. Hospicjum dla dzieci przeznaczone jest dla pacjentów poniżej 18 roku życia z chorobami nowotworowymi i innymi, które nie dają nadziei na wyleczenie oraz pacjentów, których stan zdrowia lub sytuacja rodzinna nie pozwala na przebywanie w domu. Oddziały dla dzieci są częścią hospicjów stacjonarnych dla dorosłych. Również domowe hospicja dla dzieci posiadają sale do krótkich pobytów dzieci wymagających intensywnej opieki, rehabilitacji lub opieki wyręczającej rodziny obciążone nieustannym czuwaniem przy dziecku․ W większości hospicjów dla dzieci prężnie działa wolontariat, a ochotnicy przechodzą specjalistyczne szkolenia, by odpowiedzieć na problemy małych pacjentów i ich rodzin, w tym szczególnie rodziców i rodzeństwa ciężko chorych dzieci ${ }^{8}$.

Oddział medycyny paliatywnej. To rodzaj hospicjum w strukturze publicznego szpitala, będący najczęściej zaadaptowanym do tego celu oddziałem lub jego częścią. Trafiają tam pacjenci z innych oddziałów: interny, onkologii, chirurgii. Formalności związane ze znalezieniem wolnego łóżka są obowiązkiem szpitala. Skierowanie wystawiane jest tylko wtedy, gdy wyczerpią się już wszystkie możliwości poprawy stanu pacjenta, a choroba i inne przykre

i zobowiazanie, w: Podręcznik koordynatora wolontariatu hospicyjnego, red. P. Krakowiak, A. Modlińska, J. Binnebesel, Gdańsk 2008, s. 63-70.

A. Modlińska, Wolontariat medyczny, dz. cyt., s. 59-60.

A. Czerwiński, Gdzie po pomoc?, dz. cyt., s. 20.

8 Por. Z. Bohdan, Wolontariat hospicyjny wśród dzieci i mtodzieży - szczególne wyzwanie i zobowiqzanie, dz. cyt., s. 64-69. 
objawy (na przykład niepoddające się leczeniu odleżyny, wymioty, duszność) wymagają opieki szpitalnej na oddziale medycyny paliatywnej. W większości tych oddziałów mogą działać wolontariusze, choć nie zawsze zezwalają na to formalne struktury publicznej placówki zdrowotnej9.

Poradnia medycyny paliatywnej i leczenia bólu. $\mathrm{Z}$ założenia tę formę opieki sprawuje się po zakończeniu leczenia przyczynowego (onkologicznego) nad chorymi, którzy mogą przybyć do poradni, a także tymi, którzy nie są w stanie przyjść i wymagają wizyt domowych, jednak rzadziej niż w domowej opiece hospicyjnej. Chorzy ci z czasem potrzebują zwykle częstszych wizyt lub ciągłej opieki, dlatego po wizytach poradnianych zaczynają korzystać z hospicjum domowego lub stacjonarnej opieki paliatywno-hospicyjnej. W tej formie opieki zwykle nie ma miejsca na zaangażowanie wolontariuszy, choć są ośrodki, które wykorzystują ochotników jako kierowców do transportu chorych $z$ domów do poradni ${ }^{10}$. Powstają także szpitalne zespoły wspierające, których zadaniem jest przeprowadzenie chorego $z$ leczenia przyczynowego do opieki paliatywnej i wspieranie go zwłaszcza w sytuacji konieczności terapii bólu lub innych objawów związanych z przebiegiem choroby ${ }^{11}$.

Dzienny pobyt dla pacjentów opieki paliatyw$n$ e j. Nową formą opieki z udziałem wolontariuszy, która $z$ trudnościami toruje sobie drogę $\mathrm{w}$ systemie ochrony zdrowia, są oddziały pobytu dziennego dla chorych o stosunkowo dobrej kondycji fizycznej. Powodem słabego rozwoju tej formy opieki są problemy $z$ finansowaniem tych usług przez NFZ, a często z pomocą przychodzą samorządy i organizacje pozarządowe dostrzegające pilną potrzebę tego rodzaju formy pomocy. Odpowiednio przygotowani i koordynowani wolontariusze moga spełnić wiele ważnych funkcji w tego rodzaju instytucjach, które powinny stanowić w przyszłości ważną część oferty opiekuńczej ${ }^{12}$.

9 P. Krakowiak, Spoteczne i edukacyjne funkcje opieki paliatywno-hospicyjnej, dz. cyt., s. 140-148.

10 Tamże.

11 A. Modlińska, Wolontariat medyczny, dz. cyt., s. 61-62.

12 P. Krakowiak, Wolontariat w opiece u kresu życia, dz. cyt., s. 188. 
Grupy wsparcia w żałobie dla dorosłych i dla dzieci. W opiece paliatywno-hospicyjnej opieką otaczani są chorzy, ale także ich bliskim udziela się pomocy socjalnej i wsparcia psychologicznego oraz duchowego. Grupy wsparcia w żałobie są otwarte dla wszystkich po stracie bliskiej osoby. Szczególną wagę przywiązuje się do wsparcia dzieci i młodzieży, organizując spotkania psychopedagogiczne i wyjazdy integracyjne. W razie potrzeby dostępna jest także interwencja kryzysowa i indywidualna pomoc psychologiczna. Wiele ośrodków paliatywno-hospicyjnych prowadzi grupy wsparcia $\mathrm{w}$ żałobie. Wolontariat związany $\mathrm{z}$ towarzyszeniem osieroconym jest szczególnym wyzwaniem, do którego potrzeba przygotowania, a w większości ośrodków sprawujących tę formę opieki ochotnikami są studenci psychologii, pedagogiki i innych kierunków pomocowych, koordynowani przez osobę odpowiedzialną za pomoc osobom w żałobie ${ }^{13}$.

\section{Definicje wolontariatu i wolontariat hospicyiny}

Definicja wolontariatu określa go jako bezpłatne, dobrowolne, świadome działanie na rzecz innych, wykraczające poza więzi rodzinno-koleżeńsko-przyjacielskie. Najczęściej wyróżniane rodzaje wolontariatu, to: bezterminowy, krótkoterminowy, jednorazowy, okresowy, indywidualny, grupowy itd. (www.wolontariat.org.pl, odczyt: 30.01.2015). Według obowiązującego w Polsce prawa wolontariusz to osoba, która ochotniczo i bez wynagrodzenia wykonuje świadczenia na zasadach określonych w ustawie (Ustawa z dnia 24 kwietnia 2003 r. o działalności pożytku publicznego i o wolontariacie, Dz.U. 2003, nr 96, poz. 873). Istniejące w Polsce sieci wolontariatu pozwalają każdemu chętnemu odnaleźć miejsce, gdzie może pomagać osobom lub instytucjom wspierającym potrzebujących. Szczególnym rodzajem wolontariatu, posiadającym jedną z najdłuższych historii spośród aktywnie działających grup ochotników, jest wolontariat hospicyjny. Przyjrzenie się jego rozwojowi na świecie i w Polsce pozwoli zrozumieć jego szczególną specyfikę, która daje możliwość oddziaływania na młodzież zagrożoną ryzykiem wykluczenia.

Tamże, s. 157-158.. 
Wolontariat hospicyjny. Ochotnicze zaangażowanie w pomoc ciężko chorym na choroby nowotworowe wiąże się nieodłącznie z początkami współczesnego ruchu hospicyjnego na świecie i w Polsce. Wolontariusze w naszym kraju zapisali chlubną kartę w pierwszych latach organizowania opieki domowej ${ }^{14}$, a integracja $\mathrm{z}$ profesjonalizującą się nową dziedziną służby zdrowia dała $\mathrm{w}$ konsekwencji zaangażowanie całego społeczeństwa w poprawę opieki dla nieuleczalnie chorych, a także wsparcie w okresie umierania i śmierci. Cicely Saunders wraz z grupą ochotników doprowadziła do powstania Hospicjum św. Krzysztofa w Londynie, będącego wzorem nowoczesnej opieki paliatywno-hospicyjnej. Ważną rolę w procesie powstawania i działania tego ośrodka pełnili i nadal pełnią wolontariusze ${ }^{15}$. Model brytyjski stał się wzorem dla świata anglosaskiego, a później dla innych krajów, które oprócz profesjonalnej opieki paliatywnej włączają do opieki także odpowiednio przygotowanych do tej posługi wolontariuszy ${ }^{16}$. W Polsce pierwszą grupą wolontariatu hospicyjnego był zespół opieki powstały w Krakowie na bazie długoletniej pracy pielęgniarki Hanny Chrzanowskiej. Po jej śmierci ważną rolę w procesie popularyzacji idei hospicyjnej odegrała publicystka Halina Bortnowska oraz działania wielu wolontariuszy, które doprowadzily do powstania w 1981 roku Towarzystwa Przyjaciół Chorych Hospicjum. Kolejnym ośrodkiem wolontariatu hospicyjnego było środowisko Akademii Medycznej w Gdańsku. „Osobiste doświadczenia wrażliwego kapelana, ogólna wiedza o współczesnym ruchu hospicyjnym zaczerpnięta ze spotkania z Panią Cicely Saunders były fundamentami teoretycznych podstaw dzieła hospicyjnego. W centrum uwagi pozostawał zawsze ciężko chory człowiek, jego rodzina i bliscy. [...] Spotkania odbywały się wówczas raz w miesiącu u pallotynów w Gdańsku, przy ul. Skłodowskiej-Curie. Zespół składał się z 15-20 osób”17.

14 Zob. Dzieje Pallotyńskiego Hospicjum w Gdańsku 1983-2013, red. P. Krakowiak, A. Janowicz, Gdańsk 2013, s. 34-49.

15 Zob. D. Clark, N. Small, M. Wright, M. Winslow, N. Huges, A Bit of Heaven for the Few? An Oral History of the Modern Hospice Movement in the United Kingdom, Lancaster 2005.

16 Zob. Volunteers in Hospice and Palliative Care. A Handbook for Volunteer Service Managers, red. D. Doyle, London 2002.

17 Ksiqdz Eugeniusz Dutkiewicz SAC. Ojciec ruchu hospicyjnego w Polsce, red. P. Krakowiak, A. Stolarczyk, Gdańsk 2007, s. 83. 
Do czasu oficjalnego uznania opieki paliatywno-hospicyjnej jako elementu systemu ochrony zdrowia w Polsce działało kilkadziesiąt ośrodków domowej opieki hospicyjnej opartych wyłącznie na posłudze wolontariatu, świadczonej zarówno przez personel medyczny, tj. lekarzy, pielęgniarki i innych pracowników służby zdrowia, jak również przez duchownych. Wraz z włączeniem opieki paliatywno-hospicyjnej do systemu ochrony zdrowia zmieniły się wymagania dotyczące świadczenia opieki medycznej, ale mimo to dużą część zespołu stanowią nadal wolontariusze. Zaangażowanie wolontariatu jest uważane za ważny element opieki paliatywno-hospicyjnej na arenie międzynarodowej. W listopadzie 2003 roku Komitet Ministrów dla państw członkowskich Rady Europy ustanowił Wytyczne dotyczące organizacji opieki paliatywnej ${ }^{18}$. Uznają one pracę wolontariuszy, „opiekunów, których działalność jest częściowo, choć nie całkowicie specyficzna dla opieki paliatywnej” za ważną, choć często niedocenianą. Zgodnie $\mathrm{z}$ prezentowanymi w Rekomendacjach poglądami „Obecność trzeciej osoby pozwala choremu poczuć się czyimś partnerem i być postrzeganym jako osoba żyjąca, która ciągle stanowi część społeczeństwa" ${ }^{19}$. Rekrutację, szkolenie i formację stałą wolontariuszy hospicyjnych zapewniają koordynatorzy wolontariatu, którzy są przygotowywani i szkoleni do pełnienia ważnej roli $\mathrm{w}$ zespole hospicyjnym ${ }^{20}$. Pomimo wieloletniej tradycji pojawiają się realne obawy dotyczące możliwości zmniejszania się chętnych do wolontariatu hospicyjnego. Wiele ośrodków zgłasza problemy związane $\mathrm{z}$ rekrutacją i naborem nowych kandydatów do pomocy ciężko chorym i umierającym, co potwierdzają także doniesienia i analizy hospicyjnej rzeczywistości ${ }^{21}$. Jednym ze sposobów przeciwdziałania tym obecnym od kilku lat tendencjom były inicjatywy Krajowego Duszpasterza Hospicjów i Fundacji Hospicyjnej oparte na działa-

18 Rada Europy, Wytyczne (Rekomendacje) Rec (2003) 24 Komitetu Ministrów dla państw cztonkowskich dotyczace organizacji opieki paliatywnej, przeł. W. Leppert, A. Orońska, A. Szczerbak, S. Woźniak, red. polskiej wersji dokumentu J. Łuczak, Poznań 2004.

19 Tamże, s. 61.

20 Podręcznik koordynatora wolontariatu hospicyjnego, red. P. Krakowiak, A. Modlińska, J. Binnebesel, Gdańsk 2008, s. 151-156.

21 J. Wygnański, Czy zaczyna się kryzys wolontariatu? „Wiadomości Hospicyjne" 2009, nr 3, s. 28-29. 
niach edukacyjnych na temat końca życia. $\mathrm{W}$ ich wyniku powstał szereg podręczników i pomocy multimedialnych, przeprowadzono cykle szkoleń dla nauczycieli i wolontariuszy. Ogólnopolskie działania wzmocniły rolę wolontariatu w opiece paliatywno-hospicyjnej, rozszerzyły zakres społecznej edukacji i pozwoliły na użycie wolontariatu jako narzędzia do działań integracyjnych i włączających różne osoby i grupy społeczne we wspólne działania charytatywne i opiekuńcze $^{22}$. Działania te w koniecznym skrócie zostaną przedstawione poniżej.

\section{Ogólnopolski program rozwoju wolontariatu hospicyjnego „Lubię pomagać"}

Krajowy Duszpasterz Hospicjów wraz z Fundacją Hospicyjną przygotowali program, złożony i zaakceptowany przez Fundację PZU jako partnera tego ogólnopolskiego działania na rzecz rozwoju wolontariatu hospicyjnego. W 2007 roku włączyło się do niego ponad 100 ośrodków, a $90 \mathrm{z}$ nich ukończyło pierwszy rok programu. W ramach tego projektu odbyły się szkolenia dla koordynatorów wolontariatu, nauczycieli i wolontariuszy. Powstał także wortal dla wolontariuszy (www.wolontariat.hospicja.pl), na którym zarówno koordynatorzy, jak i wolontariusze oraz kandydaci do wolontariatu mogą znaleźć wiele informacji przydatnych w codziennej pracy. Przeszkoleni koordynatorzy wolontariatu otrzymali Podręcznik koordynatora wolontariatu hospicyjnego, który był pierwszą publikacją tego typu w Polsce i jedną z pierwszych w Europie ${ }^{23}$. Także dla wszystkich kandydatów do wolontariatu hospicyjnego, poczynając od uczniów i studentów, poprzez osoby dorosłe i starsze, został przygotowany Podręcznik wolontariusza hospicyjnego ${ }^{24}$. Drugi rok

22 Zob. Lubie pomagać! Program rozwoju wolontariatu hospicyjnego 20072010, red. A. Janowicz, P. Krakowiak, O. Woźniak, Gdańsk 2010, s. 19-30.

23 K. de Walden-Gałuszko, Wprowadzenie, w: Podręcznik koordynatora wolontariatu hospicyjnego, red. P. Krakowiak, A. Modlińska, J. Binnebesel, Gdańsk 2008, s. XXV.

24 Zob. Podręcznik wolontariusza hospicyjnego, red. P. Krakowiak, A. Modlińska, Gdańsk 2008. 
trzyletniego projektu został w całości przeznaczony na edukację w polskich szkołach na temat końca życia i wolontariatu hospicyjnego. Cykl warsztatów dla nauczycieli, katechetów i wychowawców odbył się we wszystkich regionach kraju, gromadząc ponad 300 nauczycieli. Wspólpraca z nimi jest jednym z elementów wprowadzania do szkół tematyki związanej ze śmiercią i towarzyszeniem w żałobie. Większość ośrodków paliatywno-hospicyjnych aktywnie współpracuje już ze szkołami, ale wielokrotnie udało się zachęcić do współpracy szkoły i hospicja z sąsiedztwa. Wyniki szkoleń ukazały jak potrzebne jest podejmowanie tego rodzaju tematów wśród nauczycieli, którzy często muszą się zmagać z pełnymi emocji doświadczeniami uczniów w obliczu choroby czy umierania. Liczne wypowiedzi zebrane od uczestników warsztatów dla nauczycieli potwierdzają jak bardzo brakuje wiedzy i doświadczenia w radzeniu sobie $\mathrm{z}$ dramatami, które stają się udziałem dzieci i młodzieży. Zwykle w takich trudnych sytuacjach kierują się intuicją, ale zawsze pozostaje niepewność, czy na pewno zrobiło się wszystko, czy na pewno dobrze? Tym bardziej, że młodzież w różnym wieku inaczej reaguje w obliczu straty, inaczej się zachowuje i nie ma jednej uniwersalnej recepty.

Rozmowy o końcu życia w polskiej szkole. Owocem działań edukacyjno-szkoleniowych i współpracy z nauczycielami odnośnie do końca życia, osierocenia i żałoby jest przygotowana przez Fundację Hospicyjną książka: Jak rozmawiać z uczniami o końcu życia $i$ wolontariacie hospicyjnym ${ }^{25}$. Jest to konkretna pomoc psychopedagogiczna dla nauczycieli w towarzyszeniu dzieciom i młodzieży od chwili ciężkiej choroby czy nagłego wypadku w klasie lub najbliższym otoczeniu uczniów, aż po wsparcie po stracie i porady jak towarzyszyć w żałobie. Książka składa się z trzech głównych części. Pierwsza $z$ nich dotyczy zagadnień omawianych przez specjalistów z psychologii, pedagogiki, filozofii, teologii oraz praktycznego jej zastosowania do współpracy szkół i instytucji pomocowych. Oto fragment pierwszej części książki i zadania tanatopedagogiki w kontekście działalności społecznej. 
W treściach kształcenia tanatopedagogicznego należy uwzględnić ruch społeczny na rzecz chorych, cierpiących i umierających, którego przejawem są instytucje, grupy wolontariackie i grupy wsparcia dla potrzebujących w różnych sytuacjach życiowych. [...] W Polsce do najbardziej znanych należy ruch wolontariatu hospicyjnego i realizowana pod jego patronatem kampania Hospicjum to też Życie. Fundacja Wielka Orkiestra Świątecznej Pomocy, poza organizowaniem corocznych kwest $\mathrm{np}$. dla szpitali dziecięcych, zajmuje się m.in. szkoleniami w zakresie pierwszej pomocy. Zadaniem nauczycieli jest przygotowanie swych podopiecznych do uczestnictwa w pracach tego rodzaju instytucji, poprzez informowanie o ich działalności i zachęcanie do podjęcia współpracy [...]. Aby nie narażać wychowanków na szok związany z kontaktem z cierpieniem, chorobą i śmiercią, powinno się ich szkolić, najlepiej przez osoby mające praktykę w pracy wolontaryjnej i mogące przekazać nie tylko wiedzę o korzyściach z niej płynących, ale także o wymogach stawianych wolontariuszom i zagrożeniach w sferze zdrowia fizycznego i psychicznego. Nie każdy bowiem nadaje się do tego rodzaju pracy, mimo szczerych chęci i zainteresowania. Rolą nauczyciela jest więc orientowanie się w predyspozycjach podopiecznego i doradzanie odpowiedniej formy aktywności społecznej ${ }^{26}$.

Kolejne rozdziały są praktycznym wskazaniem sposobów nawiązywania współpracy $z$ centrum wolontariatu hospicyjnego od pierwszego spotkania w szkole, poprzez pomoc w akcjach charytatywnych czy wydarzeniach kulturalnych, aż do wizyty w ośrodku hospicyjnym. Skierowane bezpośrednio do pedagogów słowa najlepiej odpowiadają na częste obawy i pytania ze strony nauczycieli:

Nauczycielu, pamiętaj: w dużej mierze to od Ciebie zależy, jaką formą wolontariatu zainteresuje się twój uczeń; nie obawiaj się, że młodzież jest zbyt wrażliwa; trudne tematy i tak się pojawią; koordynator wolontariatu jest po to, by pomóc ci odpowiadać na trudne pytania bądź wskazać ci odpowiednią osobę, która to zrobi za niego; każda forma wolontariatu to kształtowanie nowych zainteresowań. Wolontariat może być doskonałym bodźcem dla młodzieży uczącej się świata; wolontariat nie ocenia, nie pyta o gusta, zasobność portfela, poglądy czy religię. Wolontariuszem może być każdy, jednak nie każdy jest odpowiedni do wykonywania każdego rodzaju prac; wolontariat to nie tylko

P.P. Grzybowski, Praktyczne cele $i$ aspekty ksztatcenia tanatologicznego pedagogów i nauczycieli, w: Jak rozmawiać z uczniami o końcu życia i wolontariacie hospicyjnym, red. J. Binnebesel, A. Janowicz, P. Krakowiak, Gdańsk 2009, s. 15. 
dawanie - pomagając, wiele otrzymujesz w zamian; podając za Matką Teresą z Kalkuty: „Rzecz nie w wielkości czynu, ale w wielkości miłości, jaką w najdrobniejszy czyn wkładamy"27.

Ostatnią część książki stanowią konkretne narzędzia dydaktyczne przygotowane przez nauczycieli, katechetów, psychologów i pedagogów szkolnych i wychowawców współpracujących w projekcie „Lubię pomagać”. Niewątpliwą zaletą konspektów i scenariuszy zajęć dla różnych poziomów nauczania jest osadzenie proponowanych tematów na doświadczeniach kryzysów przeżytych przez nauczycieli razem z uczniami czy na doświadczeniach współpracy z hospicjami. W obu przypadkach te pomoce dydaktyczne są gotowym narzędziem dla pedagogów i psychologów w sytuacjach kryzysowych, gdy w rzeczywistości szkoły przyjdzie się zmierzyć z doświadczeniem kryzysu, wypadku czy śmierci. Niech wypowiedź jednej z nauczycielek będzie zachętą, by sięgnąć po te pomoce:

Kiedyś usłyszałam „śmierć jest końcem umierania i wejściem w życie, nowe życie”. Czas odchodzenia, terminalna faza choroby jest jednak trudnym okresem i powinien on przebiegać w sposób godny, godny dla człowieka, w poczuciu bliskości z innymi. Ze świadomością śmierci powinien żyć każdy. Myślę, że praca młodzieży na rzecz hospicjum dogłębniej przybliża jej i uświadamia tę rzeczywistość - rzeczywistość śmierci. Pracując z młodymi ludźmi, staram się uczulić ich na potrzeby innych ludzi. Zachęcam ich do pracy w wolontariacie, by zechcieli ofiarować trochę swojej młodości, radości, sił i entuzjazmu. Tego rodzaju działalność jest bardzo ważna dla mnie i dla młodzieży, gdyż jako wolontariusze otrzymujemy wynagrodzenie niematerialne - spełnienie swoich motywacji: poczucie sensu służby drugiemu człowiekowi, uznanie, podwyższenie samooceny ${ }^{28}$.

Kolejnymi książkami, które powstały w ramach tego projektu były Pozamedyczne aspekty opieki paliatywno-bospicyjnej" ${ }^{29}$, a także

27 A. Tuchacz, Na czym polega praca nauczyciela hospicyjnego centrum wolontariatu i koordynatora wolontariatu, w: Jak rozmawiać z uczniami o końcu życia $i$ wolontariacie hospicyjnym, red. J. Binnebesel, A. Janowicz, P. Krakowiak, Gdańsk 2009, s. 108.

28 M. Kozik, wypowiedź na temat korzyści współpracy hospicjów i szkól, w: Jak rozmawiać z uczniami o końcu życia $i$ wolontariacie hospicyjnym, red. J. Binnebesel, A. Janowicz, P. Krakowiak, Gdańsk 2009, s. 114.

29 Zob. Pozamedyczne aspekty opieki paliatywno-hospicyjnej, red. J. Binnebesel, A. Janowicz, P. Krakowiak, A. Paczkowska, Gdańsk 2010. 
praktyczne poradniki Przewlekle chory w domu. Poradnik dla rodzin i opiekunów ${ }^{30}$ oraz Przerwlekle chore dziecko w domu. Poradnik dla rodziny i opiekunów ${ }^{31}$. Naukowym zwieńczeniem tego ogólnopolskiego projektu, który przez trzy lata poprawił zespołową opiekę paliatywno-hospicyjną i stworzył komplet narzędzi przydatnych do rekrutacji, szkolenia i koordynacji wolontariuszy jest publikacja Spoteczne i edukacyjne funkcje opieki paliatywno-hospicyjnej. Badanie w dziataniu 2002-201032. Szczególowy opis rezultatów tych działań wykracza poza ramy tego artykułu, w którym zostaną przedstawione formy oddziaływania na trudną młodzież trafiającą do wolontariatu opieki paliatywno-hospicyjnej.

\section{Szczególne formy wolontariatu hospicyjnego adresowane do młodzieży zagrożonej wykluczeniem}

Wolontariat osób niedostosowanych społecz$\mathrm{n}$ i e. Koordynatorzy wolontariatu, oprócz pozyskiwania kandydatów z liceów i wyższych uczelni w swoim rejonie, są otwarci także na uczniów w szkołach ponadgimnazjalnych, nazywanych „zawodówkami”. Na podstawie doświadczeń wolontariatu hospicyjnego i świadectw wielu nauczycieli biorących udział w warsztatach „Lubię pomagać” można stwierdzić, że umiejętne wprowadzenie wolontariatu do grupy młodzieży tzw. „trudnej” może być skutecznym narzędziem edukacyjnym. Często $w$ tej grupie jest duża liczba osób z grupy podwyższonego ryzyka przestępczości, które określa się mianem niedostosowanych społecznie. Czy wolontariat hospicyjny może być sposobem na dostosowanie tych osób do życia społecznego? Do szkół zawodowych trafiają uczniowie, którzy podczas egzaminu gimnazjalnego osiągnęli wyniki przeciętne i poniżej (średnio ok. 60 punktów). Pochodzą zasadniczo z rodzin

Zob. Przewlekle chory w domu. Poradnik dla rodzin i opiekunów, red. P. Krakowiak, D. Krzyżanowski, A. Modlińska, Gdańsk 2010.

31 Przerwlekle chore dziecko w domu. Poradnik dla rodziny i opiekunów, red. J. Binnebesel, Z. Bohdan, P. Krakowiak, D. Krzyżanowski, A. Paczkowska, Gdańsk 2011.

32 Zob. P. Krakowiak, Spoteczne i edukacyjne funkcje opieki paliatywno-hospicyjnej. Badania w dziataniu 2002-2010, Gdańsk 2012. 
uboższych, słabiej wykształconych, często obciążonych różnorodnymi problemami i dysfunkcyjnych. Najczęściej już mają za sobą konflikty z prawem, zażywają narkotyki i nie stronią od alkoholu. Uczęszczanie do „złej” szkoły sprawia, że czują się oni na marginesie edukacji i społeczeństwa, bez szans na życiowy sukces. Pragną zainteresowania i chcą zwrócić na siebie uwage poprzez negatywne zachowanie i łamanie prawa. Są twardzi i niedostępni jedynie zewnętrznie, ale po bliższym spotkaniu z nimi okazuje się, że obawiają się okazywania uczuć, bojąc się zranienia. Sądzą, że bycie wrażliwym jest oznaką słabości, choć jednocześnie będąc wrażliwi potrzebują narkotyków ${ }^{33}$. Najczęściej przeżywają poczucie zagubienia i braku perspektyw w życiu. Koordynator wolontariatu na zajęciach w szkole lub na spotkaniu w ramach rekrutacji do wolontariatu powinien się spodziewać negatywnych reakcji i niedowierzania, że do tej grupy ludzi przychodzi się z pozytywną propozycją pomocy drugiemu człowiekowi. Właśnie na tym paradoksie może jednak polegać sukces zaangażowania „trudnej młodzieży” do wolontariatu hospicyjnego.

Pojęcie niedostosowania społecznego nie jest pojęciem jednoznacznym ${ }^{34}$. Należy jednak zastanowić się, czy osoby niedostosowane społecznie, czyli takie, które weszły w konflikt z prawem, używają narkotyków, należą do subkultur młodzieżowych, mogą pełnić rolę wolontariuszy hospicyjnych. Istniejący stereotyp wolontariusza hospicyjnego to pobożny i zaangażowany uczeń liceum, wrażliwy i otwarty na pomoc innym. Trudni uczniowie „zawodówek” bywają gruboskórni, brak im ogłady i kultury, a ich odbiór społeczny nie jest dobry. W pierwszym kontakcie zdają się mówić do przychodzących do nich dorosłych: „Nic nam się nie chce, jesteś obcy”, lub bardziej radykalne: „Wiemy, że jesteśmy gorsi, nie mamy szans i że nami pogardzasz". Jak do nich dotrzeć? Czy angażowania ich w wolontariat hospicyjny ma w ogóle sens? Doświadczenia kapelana hospicyjnego i katechety z Pucka dowodzą, że jest to możliwe

33 Por. P. Kwiatkowski, Miękkie narkotyki i ich używanie przez mtodzię̇ w świetle wybranych teorii, w: Dewiacyjne aspekty wspótczesnego świata, red. M. Prokosz, Toruń 2004, s. 107-109.

34 Zob. Por. P. Gindrich, Psychospoteczne komponenty niedostosowania, Lublin 2007. 
i wskazują na proces włączenia uczniów zagrożonych wykluczeniem do wolontariatu ${ }^{35}$.

Uczniowie "zawodówek" w wolontariacie. Pierwszym etapem ich wolontariatu może być wolontariat akcyjny, związany z podstawowymi dla działania każdego ośrodka paliatywno-hospicyjnego akcjami charytatywnymi. Kolejnym, ze względu na męską specyfikę grupy, może być „wolontariat techniczny” związany z naprawą sprzętu, służbą w charakterze kierowców zespołu wyjazdowego czy konserwacją i troską o samochody hospicyjne. Zajęcia dają młodym ludziom poczucie, że są fachowcami, coś potrafią, wyrabiając $w$ nich także poczucie odpowiedzialności za mienie hospicyjne i za chorych, którym służą. Częste sięganie po alkohol i zażywanie „miękkich” narkotyków demotywuje uczniów i sprawia, że nie mają poczucia odpowiedzialności ${ }^{36}$. Dyżury kierowcy hospicyjnego, współpraca z członkami zespołu hospicyjnego uczą punktualności i wymagają trzeźwości. Ostatnim etapem wolontariatu dla młodych ludzi z „zawodówek” może być wolontariat medyczny. Uczniowie ci, po starannej selekcji i fachowym przeszkoleniu, mając kontakt z chorymi, uczą się na nowo odczuwania emocji. Zaczynają okazywać uczucia, uświadamiają sobie, że tak zwane „prawdziwe życie” dostarcza więcej prawdziwych emocji niż sztuczne stymulowanie się narkotykami. Niektórzy z nich w ramach wolontariatu hospicyjnego mogą także odbywać wyroki ograniczenia wolności, które najczęściej orzekają sądy w drobnych sprawach związanych z przestępczością narkotykową i $z$ innymi zachowaniami aspołecznymi ${ }^{37}$. Niezbędna jest wobec wolontariuszy z „zawodówek” cierpliwość i żelazna konsekwencja, jak również jasne reguły działania, z akceptacją pomyłek, niedociągnięć i wpadek w procesie uczenia się służby hospicyjnej. Jest to ważne, gdyż uczniowie ci są przyzwyczajeni, że nikt im nie ufa, nie przyznając im prawa do błędu czy słabości. Natomiast na ich niepowodzenia środowiska domowe i szkolne reagują agresją i negacją ich dobrej woli. W sytuacjach konfliktowych

35 J. Kaczkowski, Wolontariat osób niedostosowanych spotecznie, w: Podręcznik koordynatora wolontariatu hospicyjnego, red. P. Krakowiak, A. Modlińska, J. Binnebesel, Gdańsk 2008, s. 49-53.

36 Por. P. Kwiatkowski, Miękkie narkotyki i ich używanie przez mtodzież w świetle wybranych teorii, dz. cyt., s. 109.

37 J. Kaczkowski, Wolontariat osób niedostosowanych spotecznie, dz. cyt., s. 50-52. 
należy zawsze odnosić się do czynu, a nie osoby, w myśl pedagogicznej zasady, według której nie należy nigdy mówić: „Jesteś głupi”, tylko: „To, co zrobiłeś, było głupie”. Pracując z ludźmi zagrożonymi wykluczeniem, pogubionymi i pozbawionymi perspektyw z powodu sytuacji rodzinnej i osobistej, należy postawić na ciągłe podkreślanie pozytywnych wartości $\mathrm{w}$ ich zachowaniach i oferowanej przez nich pomocy. Koordynator wolontariatu i pozostali członkowie zespołu powinni chwalić ich za każdą dobrą inicjatywę i pomoc. Wprowadzanie młodych ludzi z „zawodówek” w działania wolontariatu może wydawać się bardziej ryzykowne niż w przypadku młodzieży z tak zwanych „dobrych domów”. Wolontariusze ze szkół mniej renomowanych dzięki odpowiedzialności powierzonej im w wolontariacie mogą odzyskać poczucie własnej wartości oraz bycia potrzebnym, a do ich życia może powrócić wiara w sens i cel możliwy do osiągnięcia. Rekrutacja wolontariuszy z grup zagrożonych wykluczeniem jest trudniejsza, ale po wejściu do grupy i obdarzeniu ich zaufaniem mogą być oni podporą zespołu, nie szczędząc czasu na pomoc. Mówią o centrum wolontariatu: „To mój drugi dom" i potrafią dla tego domu, jego mieszkańców i chorych zrobić bardzo wiele. A najważniejsze jest to, że odnajdują sens i cel swojego życia.

\section{Wolontariat hospicyjny jako sposób na rozwój emocjonalny trudnej młodzieży}

Pozytywne działania edukacyjne wolontariatu hospicyjnego zostały opisane zarówno $\mathrm{w}$ podręczniku wspóltworzonym przez nauczycieli i wychowawców $w^{38}$, jak również potwierdzone w badaniach po zakończeniu ogólnopolskiego projektu „Lubię pomagać”39. Przedstawione wyżej praktyki ukazały możliwość włączania do wolontariatu młodzieży zagrożonej wykluczeniem, a także dają nowe możliwości edukacyjne i resocjalizacyjne. $\mathrm{W}$ wyborze przyszłych

38 Jak rozmawiać z uczniami o końcu ̇̇ycia $i$ wolontariacie hospicyjnym, red. J. Binnebesel, A. Janowicz, P. Krakowiak, Gdańsk 2009.

39 P. Krakowiak, Spoteczne i edukacyjne funkcje opieki paliatywno-hospicyjnej, dz. cyt. 
profesji dzieci, jak i młodzież orientują się na swój rozwój poprzez testy kompetencyjne, wybory specjalności, przedmiotów wiodących czy dodatkowych zajęć pozalekcyjnych. Także wolontariat hospicyjny może pomóc w wyborze powołania życiowego. Dotyczy to szczególnie pomocy człowiekowi w kryzysie, któremu psychologia, pedagogika specjalna, resocjalizacja, medycyna, pielęgniarstwo czy teologia starają się przyjść z pomocą. W szkole podstawowej, a na pewno w gimnazjum i szkole średniej, pojawiają się pytania o wybór szkoły i przyszłego zawodu. Wielokrotnie idealizuje się pracę lekarza czy psychologa, pedagoga lub pielęgniarki. Wolontariat hospicyjny i zaangażowanie $\mathrm{w}$ pomaganie ludziom chorym może być sposobem na sprawdzenie siebie jako osoby świadczącej pomoc. Dzieci i młodzież mogą z bliska zobaczyć ciężką pracę osób pomagających chorym w zespołach opieki hospicyjnej. Nie tylko udział $\mathrm{w}$ zespole opiekuńczym jako wolontariusz medyczny, ale każde spotkanie w ośrodku hospicyjnym i obserwacja pracy moga utwierdzić w przekonaniu o powołaniu do tej właśnie pracy lub odwieść od tego zamysłu.

Oprócz kompetencji związanych z wyborem zawodu i drogi życiowej, ważne są także umiejętności związane z posługą wolontariatu. Należą do nich: umiejętność działania w grupie, odpowiedzialność za podjęte w systemie wolontariatu zobowiązania, a także kompetencje związane $\mathrm{z}$ umiejętnością komunikacji i rozwązywania problemów personalnych ${ }^{40}$. Zarówno podczas rekrutacji do kolejnych poziomów edukacji, jak również przy przyjmowaniu na studia często brane jest pod uwagę zaangażowanie w działania wolontariatu. Również przy poszukiwaniu pracy społeczna i zespołowa praca na rzecz ludzi w potrzebie jest widziana zarówno przez pracodawców, jak i przez specjalistów od zasobów ludzkich jako cenna informacja o potencjale kandydata.

Nade wszystko jednak w wolontariacie hospicyjnym można zdobyć lub odnowić w sobie wrażliwość, która powinna cechować każdego człowieka zgodnie z najpiękniejszymi wzorami humanizmu obecnego w myśli filozoficznej przez wszystkie wieki. Drogi

40 A. Paczkowska, P. Krakowiak, B. Stachowska, Problemy i konflikty, ich rozwiązywanie i zakończenie wspótpracy w wolontariacie, w: Podręcznik koordynatora wolontariatu hospicyjnego, red. P. Krakowiak, A. Modlińska, J. Binnebesel, Gdańsk 2008, s. 169. 
do dobra wiodą przez miłość i poczucie obowiązku, gdyż celem samym w sobie jest pomoc czyniona przez człowieka dla człowieka, a jej motywacje nie stanowią kryterium oceny. Sprawcza miłość, to miłość twórcza, tworząca dobro i obdarowująca nim bliźnich ${ }^{41}$. Warto pamiętać, że cierpienie i śmierć są w życiu szkoły elementem ciągle rzadko spotykanym na zajęciach lekcyjnych i wychowawczych. Dzięki tanatopedagogicznemu przygotowaniu nauczycieli będą one mogły stanowić stały element wychowania i współpracy z rodzinami uczniów. Dyskusje o sprawach związanych z końcem życia, budzącym tak duże emocje u dzieci i młodzieży, i tak prowadzi się choćby na szkolnych korytarzach w związku ze śmiercią lub żałobą kogoś ze szkolnej społeczności. Ma to również miejsce przy okazji dramatycznych wydarzeń, o których mówią media, a także w sytuacji wypadków, katastrof, klęsk żywiołowych czy wojen, o których jesteśmy nieustannie informowani. Oprócz przewidywalnej programowości zajęć przedmiotowych szkoły, należy być przygotowanym do nieustannej zmienności problemów i nastrojów w poszczególnych klasach ${ }^{42}$. Warto rozważyć możliwość współpracy w ramach wolontariatu hospicyjnego i podjać edukację na temat końca życia, by w chwili kryzysu umieć przyjść z pomocą młodzieży zagrożonej wykluczeniem lub narażonej na izolację społeczną z powodów niepowodzeń edukacyjnych czy swojej sytuacji socjalno-bytowej lub rodzinnej. Pomoc ciężko chorym i ich bliskim może być skutecznym narzędziem włączającym „trudną młodzież” do życia społecznego, dając jej zarówno satysfakcję z wykonywania ważnej społecznie misji, jak i pozwalając odnieść życiowy sukces, który bywa trudny do osiągnięcia $\mathrm{w}$ innych dziedzinach życia szkolnego, społecznego i osobistego.

${ }^{41}$ K. Kabasiński, P. Krakowiak, Wolontariat dzieci i mtodzieży, w: Podręcznik koordynatora wolontariatu hospicyjnego, red. P. Krakowiak, A. Modlińska, J. Binnebesel, Gdańsk 2008, s. 205.

42 P.P. Grzybowski, Praktyczne cele i aspekty ksztatcenia tanatologicznego pedagogów i nauczycieli, dz. cyt. , s. 14-15. 
Bohdan Z., Wolontariat hospicyiny wśród dzieci i młodzieży - szczególne wyzwanie i zobowiqzanie, w: Podręcznik koordynatora wolontariatu hospicyjnego, red. P. Krakowiak, A. Modlińska, J. Binnebesel, „Via Medica”, Gdańsk 2008.

Clark D., N. Small, M. Wright, M. Winslow, N. Huges, A Bit of Heaven for the Few? An Oral History of the Modern Hospice Movement in the United Kingdom, Observatory Publications, Lancaster 2005.

Czerwiński A., Gdzie po pomoc?, w: Informator dla ludzi przewlekle chorych, umierajacych i ich rodzin. "Gazeta Wyborcza” 30.10.2008.

Dewiacyine aspekły współczesnego świata, red. M. Prokosz, Wydawnictwo Adam Marszałek, Toruń 2004.

Drqż̇kiewicz J., W stronę człowieka umierajacego. O ruchu hospicjów w Polsce, Uniwersytet Warszawski - Instytut Socjologii, Warszawa 1989.

Dzieje Pallotyńskiego Hospicjum w Gdańsku. Trzydzieści lat w służbie umierajqcym. 1983-2013, red. P. Krakowiak, A. Janowicz, Fundacja Hospicyina, Gdańsk 2013.

De Walden-Gałuszko K., Wprowadzenie, w: Podręcznik koordynatora wolontariatu hospicyinego, red. P. Krakowiak, A. Modlińska, J. Binnebesel, „Via Medica”, Gdańsk 2008.

Gindrich P., Psychospołeczne komponenty niedostosowania. Wybrane zagadnienia, Wydawnictwo UMCS, Lublin 2007.

Grzybowski P.P., Praktyczne cele i aspekty kształcenia tanatologicznego pedagogów i nauczycieli, w: Jak rozmawiać z uczniami o końcu życia $i$ wolontariacie hospicyinym, red. J. Binnebesel, A. Janowicz, P. Krakowiak, Fundacja Hospicyjna - „Via Medica”, Gdańsk 2009.

Jak rozmawiać z uczniami o końcu życia i wolontariacie hospicyinym, red. J. Binnebesel, A. Janowicz, P. Krakowiak, Fundacja Hospicyjna - „Via Medica”, Gdańsk 2009.

Kabasiński K., Krakowiak P., Wolontariat dzieci i młodzieży, w: Podręcznik koordynatora wolontariatu hospicyinego, red. P. Krakowiak, A. Modlińska, J. Binnebesel, „Via Medica”, Gdańsk 2008.

Kaczkowski J., Wolontariat osób niedostosowanych społecznie, w: Podręcznik koordynatora wolontariatu hospicyinego, red. P. Krakowiak, A. Modlińska, J. Binnebesel, „Via Medica”, Gdańsk 2008.

Kozik M., Wypowiedź na temat korzyści współpracy hospicjów i szkół, w: Jak rozmawiać z uczniami o końcu życia i wolontariacie hospicyjnym, red. J. Binnebesel, A. Janowicz, P. Krakowiak, Fundacja Hospicyjna - „Via Medica”, Gdańsk 2009.

Krakowiak P., Społeczne i edukacyine funkcje opieki paliatywno-hospicyjnej. Badania w działaniu 2002-2010, Studio Mediana, Gdańsk 2012.

Krakowiak P., Wolonariat w opiece u kresu życia, Wydawnictwo UMK, Toruń 2012.

Krakowiak P., Strata, osierocenie i żałoba. Poradnik dla pomagajqcych i osób po stracie, „Via Medica", Gdańsk 2007. 
Ksiqdz Eugeniusz Dutkiewicz SAC. Ojciec ruchu hospicyinego w Polsce, red. Krakowiak P., Stolarczyk A., Biblioteka Fundacji Hospicyjnej, Gdańsk 2007.

Kwiatkowski P., Miękkie narkotyki i ich używanie przez młodzież w świetle wybranych teorii, w: Dewiacyine aspekty współczesnego świata, red. M. Prokosz, Wydawnictwo Adam Marszałek, Toruń 2004.

Lubię pomagać! Program rozwoju wolontariatu hospicyinego 2007-2010, red A. Janowicz, P. Krakowiak, O. Woźniak, Fundacja Hospicyjna Hospicjum to też Życie, Gdańsk 2010.

Modlińska A., Wolontariat medyczny, w: Podręcznik koordynatora wolontariatu hospicyjnego, red. P. Krakowiak, A. Modlińska, J. Binnebesel, „Via Medica”, Gdańsk 2008.

Paczkowska A., P. Krakowiak, B. Stachowska, Problemy i konflikty, ich rozwiqzywanie i zakończenie współpracy w wolontariacie, w: Podręcznik koordynatora wolontariatu hospicyjnego, red. P. Krakowiak, A. Modlińska, J. Binnebesel, „Via Medica”, Gdańsk 2008.

Podręcznik koordynatora wolontariatu hospicyinego, red. P. Krakowiak, A. Modlińska, J. Binnebesel, „Via Medica”, Gdańsk 2008.

Podręcznik wolontariusza hospicyinego, red. P. Krakowiak, A. Modlińska, „Via Medica”, Gdańsk 2008.

Pozamedyczne aspekty opieki paliatywno-hospicyinei, red. J. Binnebesel, A. Janowicz, P. Krakowiak, A. Paczkowska, Fundacja Hospicyjna, Gdańsk 2010.

Przewlekle chore dziecko w domu. Poradnik dla rodziny i opiekunów, red. J. Binnebesel, Z. Bohdan, P. Krakowiak, D. Krzyżanowski, A. Paczkowska, Fundacja Hospicyina, Gdańsk 2011.

Przewlekle chory w domu. Poradnik dla rodzin i opiekunów, red. P. Krakowiak, D. Krzyżanowski, A. Modlińska, Fundacja Hospicyjna, Gdańsk 2010.

Tuchacz A., Na czym polega praca nauczyciela hospicyinego centrum wolontariatu i koordynatora wolontariatu, w: Jak rozmawiać z uczniami o końcu życia i wolontariacie hospicyjnym, red. J. Binnebesel, A. Janowicz, P. Krakowiak, Fundacja Hospicyjna - „Via Medica”, Gdańsk 2009.

Volunteers in Hospice and Palliative Care. A Handbook for Volunteer Service Managers, red. D. Doyle, Oxford University Press, London 2002.

Wygnański J., Czy zaczyna się kryzys wolontariatu? „Wiadomości Hospicyine” 2009, nr 3.

Rada Europy, Wytyczne (Rekomendacje) Rec (2003) 24 Komitetu Ministrów dla państw członkowskich dotyczqce organizacji opieki paliatywnej, przeł. W. Leppert, A. Orońska, A. Szczerbak, S. Woźniak, red. polskiej wersji dokumentu J. kuczak, ECEPT, Media Rodzina, Poznań 2004.

\section{Strony interne †owe:}

www.hospicja.pl

www.polanadziei.pl

www.wolontariat.hospicja.pl

www.wolontariat.org.pl 


\section{STRESZCZENIE SUMMARY}

Opieka paliatywno-hospicyina jest zwiqzana z ostatnim etapem życia ludzkiego i bywa proponowana w postaci opieki domowej lub stacjonarnej wtedy, gdy chory cierpi na zaawansowanq nieuleczalna chorobę przewlekłq głównie nowotworowq. Ciężka choroba, umieranie, śmierć oraz przeżywanie straty i żałoby sq elementami wpisanymi w misję opieki paliatywno-hospicyinej i zwiqzanego z niq w Polsce i na świecie wolontariatu. Ochotnicze zaangażowanie wiqż̇e się głównie z pomoca osób o właściwych postawach moralnych, w tym młodzieży z "dobrych szkół" czy środowisk ○ ukształtowanej duchowości i dobrych wzorcach z życia rodzinnego i społecznego. Czy jest możliwe, by tego rodzaju sytuacje graniczne o dużym ładunku emocjonalnym mogły być pozytywnymi i rozwojowymi doświadczeniami dla kształtujqcej się struktury psychofizycznej młodego człowieka zagrożonego wykluczeniem? Czy można przygotować nauczycieli i wychowawców, by poprzez tematy zwiqzane z końcem ludzkiego życia mogli wpływać na emocjonalny rozwój swoich podopiecznych, szczególnie w sytuacjach kryzysowych? Prezentując podstawowe informacje o opiece paliatywno-hospicyinej i wolontariacie hospicyinym, ukazane zostały w tym artykule przykłady udanej współpracy hospicjum i szkoły w psychopedagogicznym oddziaływaniu na młodzież z grupy zagrożonej wykluczeniem. Odniesienia do propozycji wydawniczych Biblioteki Fundacji Hospicyjnej, będqcych pomoca dla wychowawców, katechetów i innych osób pracujących $z$ tak zwanq trudnq młodzieżq kończq ten artykuł oparty na praktycznym działaniu i społecznej edukacji na temat końca ludzkiego życia i wolontariatu.
Hospice-palliative care is related to the last stage of human life and is sometimes proposed as a home or stationary care when patient is suffering from advanced, incurable chronic disease, especially cancer. Serious illness, dying, and death as well as experience of loss and bereavement are described in the mission of end-of-life care which is related in Poland with volunteering. Volunteer involvement is associated mainly with the help of people with good moral attitudes, including young people from "good schools" or environments with shaped spirituality and good practices of family and social life. Is it possible that this type of boundary situations with high emotional charge can be positive and developmental experiences for psychophysical structure emerging young person at risk of exclusion? Is it possible to prepare teachers and educators, which through the topics related to the end of life care could affect the emotional development of students, especially in crisis situations? Presenting basic information about hospice care in Poland and hospice volunteering examples of successful cooperation between hospice and school has been shown, especially its impact on young people at risk of exclusion from a group. References to publishing proposals from Hospice Foundation Library, which were prepared as help to educators, catechists and others working with so-called difficult youth ends this article based on practical action and social education about the end of life and volunteering.

\section{ADRES DO KORESPONDENCJI:}

dr hab. Piotr Krakowiak

Wydział Nauk Pedagogicznych

Uniwersytet Mikołaja Kopernika w Toruniu

ul. Gagarina 9

87-100 Toruń

pkrakow@umk.pl 